\title{
Functional Diversity of Soil Bacteria from Organic Agro Ecosystem
}

\author{
Alka Sagar ${ }^{1}$, Victor Debbarma ${ }^{2}$, Thomas Abraham², \\ Pradeep K. Shukla ${ }^{3}$ and Pramod W. Ramteke ${ }^{3 *}$ \\ ${ }^{1}$ Department of Industrial Microbiology, ${ }^{2}$ Department of Agronomy, ${ }^{3}$ Department of Biological \\ Sciences, Sam Higginbottom University of Agriculture, Technology and Sciences, \\ Allahabad 211007, India \\ *Corresponding author
}

A B S T R A C T

\section{Keywords}

Organic farming, Bacterial diversity, PGP traits, Salinity tolerance, $\mathrm{pH}$ tolerance.

\section{Article Info}

Accepted:

26 October 2017

Available Online:

10 December 2017
Organic farming is an eco-friendly agro ecosystem that helps maintain soil health in terms of biological fertility and productivity and bacterial communities in soil play an essential role. A Model Organic Farm (MOF), developed in 2002 to demonstrate organic farming modules among the farming community, is utilized to study bacterial composition, diversity, seasonal variations, and plant growth promotion (PGP) traits of the soil. We observe rich bacterial diversity in MOF soil in terms of types and PGP traits. Rich bacterial diversity in MOF soil is represented by heterotrophs, coliforms, Pseudomonas spp., Azotobacter spp. and Rhizobium spp. and majority of these microorganisms display multiple PGP traits. Bacterial isolates are predominately positive to production of ammonia (NH3) (93.2\%), indole acetic acid (IAA) (89.6), catalase (85.0), 1aminocyclopropane- 1-carboxylate deaminase (ACCD) (78.6\%) and siderophore (69.0\%). Richness of their functional characteristics is further revealed by tolerance to salinity and wide range of $\mathrm{pH}$. All the isolates are tolerant to $>5 \% \mathrm{NaCl}$ and wide range of $\mathrm{pH}$. Furthermore, majority (96-97\%) of the bacterial population of nitrogen fixers are Azotobacter spp. and Rhizobium spp. with multiple PGP traits, tolerance to salinity and wide range of $\mathrm{pH}$. The present study demonstrates that organic farming enriches soil fertility and biodiversity, as well as, less dependent on external high inputs. Thus organic farming offers promise of achieving ecological, economic and social stability in food production system.

\section{Introduction}

Modern farming practices have negatively impacted not only agricultural productivity but also soil health, food quality and environmental pollution (Ram, 2003). Recently, alternative farming systems especially organic farming is becoming popular around the globe. Organic farming has various advantages over modern agricultural practices especially sustainability and environmental safety of agricultural production. Sustainability and environmental safety of agricultural production relies on ecofriendly approaches like biofertilizers, biopesticides and crop residue return (Subramaniam et al., 2014). Organic farming relies heavily on the natural breakdown of organic matter to replace nutrients taken from the soil by crops. These eco-friendly approaches foster soil microorganisms (Bohme et al., 2005; Esperschütz et al., 2007; 
Singh et al., 2015), favoring long term soil fertility (Berger et al., 2013; Bhardwaj et al., 2014), plant tolerance and crop productivity (Bhardwaj et al., 2014), supports and strengthens productive and sustainable soil biological processes (Mader et al., 2002) and emphasizes on soil-building programmes (Abraham, 2011). Applications of biofertilizers and manure compost in organic farming system influences structure and function of soil microbial community (Marschner et al., 2003; Chu et al., 2007; Gu et al., 2009; Zhen et al., 2014; Singh et al., 2015) and the importance of microorganisms in the maintenance of quality and productivity of agricultural soils is unquestionable.

Sam Higginbottom University of Agriculture, Technology and Sciences (SHUATS) Model Organic Farm [SMOF] was developed during 2008 to 2017 under the National Project on Organic Farming (NPOF) to enthuse organic farming modules among the farming community. Under the research programme on organic certification standards of rice grown under SRI technology revealed satisfactory and promising findings with the acceptable productivity (Abraham, 2011; 2013) A corollary to high potential of organic farming for sustainable entrepreneurship by small land holders of Indo-Gangetic Plains of Asia-Pacific (Abraham et al., 2013).

The regular monitoring of soil fertility of SMOF revealed several folds increase in macro- and micro-nutrients such as available organic carbon, nitrogen, phosphorous, potassium, sulfur, zinc, iron, magnesium and copper (Abraham, 2009, 2011, 2013; Debbarma and Abraham, 2015; Abraham et al., 2016). However, information on bacterial composition, diversity, seasonal variations and plant growth promoting traits of SMOF is lacking and the present study is an effort in that direction. Our study reveals ecological, economic and social stability in food production through MOF.

\section{Materials and Methods}

\section{SHUATS Model Organic Farm [SMOF]}

SMOF, Allahabad is located at $25^{\circ} 24^{\prime} 42^{\prime \prime} \mathrm{N}$ latitude, $81^{\circ} 50^{\prime} 56^{\prime \prime} \mathrm{E}$ longitude and $98 \mathrm{~m}$ altitude above the mean sea level. It has a sub-tropical and semi-arid climate with the monsoon commencing from July and withdrawing by the end of September. About $1000 \mathrm{~mm}$ of mean annual rainfall is unevenly distributed and most of it is received during the sowing of kharif crops. Apart from this, a few winter and summer showers are also received.

Organic farming has been practiced for several decades on the campus of Sam Higginbottom University of Agriculture, Technology and Sciences, Allahabad. The SMOF covers an area of 2 hectares [5 acres] and it was further developed during 2008 to 2017 under the NPOF, which had a provision for certification, Lacon Quality Certification (P) Ltd. [Accreditation No. NPOP/NAB/006, Ministry of Commerce, Govt. of India] has been certifying SMOF during the past 7 years [Certificate No. ORG/SC/1009/001070] and is continued to-date.

\section{Collection of soil sample}

Soil samples were collected during the winter, summer and rainy seasons from the Organic Farm of SHUATS, Allahabad. The samples were placed in sterile plastic bags and kept at $40^{\circ} \mathrm{C}$ in the laboratory and analyzed within 4 $\mathrm{h}$ of collection.

\section{Isolation of bacteria}

Soil samples were serially diluted in sterile phosphate- buffered saline (Hi-media, $\mathrm{pH}$ 7.2) and inoculated on different media like Nutrient agar medium for total Heterotrophs, Kings media for Pseudomonas spp. (Ahmad et al., 2008), Yeast Extract Mannitol Agar 
(YEMA) for Rhizobium spp. (Vincent, 1970), Macconkey agar for coliform and Ashby's Agar for Azotobacteria spp. (Norris and Chapman, 1968). After incubation at $28-30^{\circ} \mathrm{C}$ for 24-48hrs, bacterial colonies were isolated. Bacterial cultures were maintained on slants at $-20^{\circ} \mathrm{C}$

Characterization of bacteria for plant growth promoting (PGP) traits

Bacterial isolates were characterized for PGP traits employing standard procedures. The following traits were analyzed.

\section{Catalase production}

Bacterial cultures were grown in nutrient agar medium for $18-24 \mathrm{~h}$ at $37^{\circ} \mathrm{C}$. The cultures were kept on clean slide with the help of loop and 2-3 drop mixed of $\mathrm{H}_{2} \mathrm{O}_{2}$ and observed the for gas bubbles. Organism producing gas bubbles was considered positive for catalase production (Schaad, 1992).

\section{Ammonia production}

Bacterial isolates were screened for the production of ammonia in peptone water. Freshly grown culture were inoculated in 10 $\mathrm{ml}$ peptone water in different tubes and incubated for 48-72 h. After 2 -3 d, Nessler's reagent $(0.5 \mathrm{ml})$ was added in each tube. Development of brown to yellow colour was considered as positive for ammonia production (Cappuccino and Sherman, 1992).

\section{Indole acetic acid (IAA) production}

IAA production was detected following method described by Brick et al., (1991). Bacterial cultures were grown in peptone water at $37^{\circ} \mathrm{C}$ for $72 \mathrm{~h}$. Full-grown cultures were centrifuged at $3000 \mathrm{rpm}$ for $30 \mathrm{~min}$. The supernatant $(2 \mathrm{ml})$ was mixed with 2 drops of orthophosphoric acid and $4 \mathrm{ml}$ of Salkowski reagent $(50 \mathrm{ml}, 35 \%$ of perchloric acid, $1 \mathrm{ml}$
$0.5 \mathrm{M} \mathrm{FeCl}_{3}$ solution). Development of pink colour indicates IAA production.

\section{$\mathrm{HCN}$ production}

$\mathrm{HCN}$ was detected according to the method of (Lorck, 1948). King's medium was amended with $4.4 \mathrm{~g}$ glycine $\mathrm{l}^{-1}$ and bacteria were streaked on agar plate. A Whatman filter paper no. 1 soaked in $2 \%$ sodium carbonate and $0.5 \%$ picric acid solution was placed at the top of the plate. Plates were sealed with parafilm and incubated at $37^{\circ} \mathrm{C}$ for 4 days. Development of yellow to red color on the filter paper indicated $\mathrm{HCN}$ production.

\section{Phosphate solubilization (PS)}

Phosphate solubilizations of isolates were evaluated from the ability to solubilize inorganic phosphate. Pikovskaya's agar medium containing calcium phosphate as the inorganic form of phosphate was used in the assay. A loop of bacterial culture was streaked on the plates and incubated at $28^{\circ} \mathrm{C}$ for 4-5 $\mathrm{d}$. The appearance of transparent halo zone around the bacterial colony indicated the phosphate solubilizing activity of the bacteria (Nautiyal, 1999).

\section{ACCD activity}

ACCD activity was detected according to the method of Safronova et al., (2006). The bacteria were grown in test tube containing $100 \mathrm{ml}$ of liquid medium: $\mathrm{KH}_{2} \mathrm{PO}_{4}(2 \mathrm{~g})$, $\mathrm{K}_{2} \mathrm{HPO}_{4}(0.5 \mathrm{~g}), \mathrm{MgSO}_{4}(0.2 \mathrm{~g})$, Glucose $(0.2 \mathrm{~g})$. The medium was supplemented with $0.3 \mathrm{~g}$ ACC or $0.19 \mathrm{~g}\left(\mathrm{NH}_{4}\right)_{2} \mathrm{SO}_{4}$ as N-source and incubated for $24-72 \mathrm{~h}$. The appearance of bacterial growth indicated the ACC deaminase activity of the bacteria.

\section{Salinity tolerance}

Isolated bacteria were inoculated in nutrient broth with different concentration of salt 
$(0.5 \%, 10 \%, 15 \%$ and $20 \%)$ and incubated for $48-72 \mathrm{~h}$ at $37^{\circ} \mathrm{C}$. After 2-3 d growth of bacteria with respect to salt concentration was observed (Damodaran et al., 2013).

\section{pH tolerance}

For determining $\mathrm{pH}$ tolerance of the isolated bacteria, they were inoculated in nutrient broth with varying $\mathrm{pH}(5,6,7,8$ and 9) and incubated $48-72 \mathrm{~h}$ at $37^{\circ} \mathrm{C}$. Observations on bacterial growth were made after $3 \mathrm{~d}$.

\section{Statistical analysis}

Statistical analysis was performed by Student's $t$-test for various comparisons.

\section{Results and Discussion}

\section{SMOF soil displays bacterial abundance and diversity}

Seasonal data reveals higher $(\mathrm{p}<0.01)$ bacterial counts in soil from organic farm in summer as compared to winter and rainy season (Table 1). Total heterotroph count 8.4 $\mathrm{x} 105 \mathrm{~g}^{-1}$ soil in summer declined to nearly half in winter and rainy season (3.5-4.0 $\mathrm{x}$ $105 \mathrm{~g}^{-1}$ soils). Though coliforms are not much studied in MOF soil, we have detected1.7- 6.0 $\mathrm{x} 10^{5} \mathrm{CFU} \mathrm{g}^{-1}$ soil in the rainy season and 2 and 3.5 folds increase in winter and summer respectively (Table 1). The versatile Pseudomonas recorded higher count in the summer, close to Heterotroph counts. A significant number of Pseudomonas and Azotobacter spp. were also observed (Table 1).

The relationship between bacteria diversity and different season were determined by a biplot (Fig. 1). It is an enhanced scatteroplot that uses both points and vectors to represent structure. The PCA biplot represents the variables with calibrated axes and observations as points allowing projecting the observations onto the axes to make an approximation of the original values of the variables. The first two principal component axis of the biplot accounted for $71.1 \%$ (F1) and $19.4 \%(\mathrm{~F} 2)$ of the total variation of the bacteria diversity and different season. In this biplot, bacteria diversity were located vary far from the origin of biplot, indicating strong bacteria diversity in different season. Eigen values of the first and second components were 2.135 and 0.583 , respectively.

\section{PGP traits among SMOF soil isolates}

Bacterial isolates $(n=650)$ from SMOF were screened for PGP traits and notably majority of them produced multiple PGP traits (Table 2). Isolates were predominately positive to production of $\mathrm{NH}_{3}$ (93.2\%), IAA (89.6), CT (85.0), ACCD (78.6\%) and SD (69.0\%). PS activity and production of $\mathrm{HCN}$ were detected in 38.0 and $27.6 \%$ isolates, respectively. Production of all PGP traits detected was higher among Pseudomonas spp. as compare to other bacterial groups isolated from organic farm (Table 2). Production of $\mathrm{HCN}$ by coliforms was lowest among all other groups of bacteria. Total heterotrophs were predominately positive to production of ammonia (97.3\%), IAA (90.6\%), siderophore $(85.9 \%)$ and catalase $(75.8 \%)$. About one third $(27.5 \%)$ of them were ACCD and HCN producers and only in $19.4 \%$ PS activity was detected (Table 2).

Pseudomonas spp. was positive for catalase, production of ammonia and IAA more than 90\% and ACCD and siderophore more than $80 \%$. Production of HCN and PS activity was observed 61.3 to $54.5 \%$ (Table 2). Of the 132 isolates of Rhizobium spp., 129 (97.7\%) and $121(91.6 \%)$ of them were positive to production of ammonia and IAA, respectively (Table 2). Production of Catalase and ACCD was detected in $117(88.6 \%)$ and $112(84.8 \%)$ of isolates of Rhizobium spp. 
Production of ammonia and IAA was detected in $96.1 \%$ isolates of Azotobacter spp. followed by catalase, siderophore and ACCD (Table 2). PS activity (26.1\%) and production of HCN $(21.5 \%)$ were the least observed PGP trait in Azotobacter spp.

Similarly among coliforms production of ammonia, catalase, IAA and ACCD was detected in $>72.8 \%$ isolates (Table 2). PS activity and production of siderophore was detected in 40.1 and $32.7 \%$ of coliforms, respectively. However, production of $\mathrm{HCN}$ was detected in only $2.8 \%$ coliform isolates (Table 2).

Seasonal variations of PGP traits among all bacterial isolates from soil of SMOF are shown in Figure 3. In all the three seasons, majority $(>60 \%)$ of heterotrophs were positive to production of ammonia, IAA, ACCD and catalase (Fig. 3A). However, in summer none of them showed siderophore activity and few of them $(<5 \%)$ were positive to PS activity. In summer none of the heterotrophs was positive to production of $\mathrm{HCN}$. As compared to rainy season significant number of heterotrophs were positive to siderophore $(\mathrm{p}<0.001)$ and PS activity $(\mathrm{p}<0.01)$ in winter season. All the coliforms were positive to catalase both in winter and rainy season and ammonia in summer season (Fig. 3B). Both in winter and summer around $80 \%$ of them showed production of IAA. ACCD activity in majority of coliforms was noted in summer season. Majority (>60\%) of Pseudomonas spp. displayed all the PGP traits in all the three seasons except production of $\mathrm{HCN}$ and PS activity in winter (Fig. 3C). Production of ammonia and catalase was $>95 \%$ isolates of Rhizobium spp. at all the three seasons (Fig. 3D). As compared to winter and summer, in rainy season production of ACCD, siderophore and PS activity was detected in significantly high number $(\mathrm{p}<0.001)$ of isolates of Rhizobium spp. As the seasonal variations are concerned for the PGP traits among Azotobacter spp., production of $\mathrm{HCN}$ was noted lowest in all three seasons as compared to other PGP traits (Fig. 3E). Production of IAA in summer and PS activity in rainy season was in significantly high ( $\mathrm{p}<0.001)$ number of Azotobacter spp. PS activity was noted least (54.5\%) among all the PGP traits and also in all three seasons as compared to other PGP traits (Fig. 3E).

Majority (93\%) of bacterial isolates from SMOF displayed multiple PGP (MPGP) traits (Table 3). Coliforms, Rhizobium spp. and Azotobacter spp. emerged as top displayer of MPGP traits followed by Pseudomonas spp. and heterotrophs (Table 3). Of the 650 total bacterial isolates examined, only 40 (6.1\%) of them were without a single PGP trait. None of the bacterial isolate displayed single PGP trait and only 3 of them showed two PGP traits.

Different bacterial groups displaying MPGP traits are depicted in Figure 2. Overall large number of isolates representing different bacterial groups displayed five MPGP traits followed by four and six MPGP traits. Over $45 \%$ nitrogen fixer representing both Rhizobium spp. and Azotobacter spp. showed five MPGP traits. Similarly Pseudomonas spp. (44.6\%) and coliforms (38.4\%) displayed six and four MPGP traits, respectively.

\section{Stress (salt and pH) tolerant PGPR}

Bacterial isolates from soil of SMOF were studied for tolerance to salt and results are given in Table 4. Majority $(74 \%)$ of the isolates were tolerant to $5 \%$ salt whereas $25 \%$ of them were tolerant to $10 \%$ salt. Only three bacterial isolates representing two coliforms and one isolate of Azotobacter spp. were tolerant to 20\% salt. Except for Azotobacter spp. large number $(>78 \%)$ of others organisms displayed tolerance to $5 \%$ salt 
(Table 4). However, tolerance to $10 \%$ of salt was highest among Azotobacter spp. (48\%) as compared to other bacterial isolates. Tolerance to $\mathrm{pH}$ among bacterial isolates from $\mathrm{SMOF}$ is given in Table 5.

The bacterial isolates from organic farm displayed tolerance to variable range of $\mathrm{pH}$. Of the 650 bacterial isolates studied for their tolerance to $\mathrm{pH}$ range, $485(74.6 \%)$ of them displayed tolerance to a wide range of $\mathrm{pH}$ 5-9 (Table 5). However, at neutral $\mathrm{pH} 7$ very few $53(8.1 \%)$ of the isolates exhibited growth.

We observe a rich bacterial diversity in soil from MOF both in terms of their types and functional (PGP) traits (Table 1 and 2; Figure 1). In the past, researchers have reported increased soil bacterial biomass, activity and bacterial functional and taxonomic richness and diversity in organic farm (Gardner et al., 2011; Lopes et al., 2011; Das and Dkhar, 2011; Grantina et al., 2011; Schmid et al., 2011; Wang et al., 2012; Stockdale et al., 2013; Hartmann et al., 2014; Lupatini et al., 2017). These workers have also reported higher population of microorganisms in organic farm in comparison to conventional farms. Several meta-analyses have revealed positive effect of organic farming on biodiversity and increase in species richness (Rahmann, 2011; Tuck et al., 2014).

Soil biodiversity is important for soil resistance and resilience (Girvan et al., 2005; Brussaard et al., 2007).
In the present investigation it observed rich seasonal bacterial diversityand biomass representing several bacterial groups such as heterotrophs, coliforms, Pseudomonas, Azotobacter and Rhizobium in MOF. We found a large number (69.0-93.2 \%) of bacterial isolates with PGP traits and majority of them displayed multiple PGP traits except for $\mathrm{HCN}$ and PS activity.

Production of ammonia was observed predominantly among isolates from MOF. In an earlier study production of ammonia was detected in $74 \%$ bacterial isolates from rhizospheric soil of chickpea of conventional farm in the vicinity of Allahabad (Joseph et $a l ., 2007)$ whereas the present study showed higher ammonia producers $(93 \%)$ from the organic farm of the same vicinity. In addition to the source of nitrogen in soil its involvement in antagonistic interactions with soil pathogens that result in disease control is reported (Saraf et al., 2008). Narula and Gupta (1986) found that inoculation of wheat and barley with ammonia excreting strains caused increased dry weight and enzyme activity.

Catalase is a very important enzyme in protecting the cell from oxidative damage by reactive oxygen species (ROS). It is well known that the products of oxygen reduction such as hydrogen peroxide can be highly toxic for cells but catalase can split hydrogen peroxide into molecular oxygen and water, preventing cells from damage by reactive oxygen species (Yao et al., 2006).

Table.1 Bacterial Diversity of soil from SMOF

\begin{tabular}{|l|l|l|l|}
\hline \multirow{2}{*}{ Organisms } & \multicolumn{3}{|c|}{ Total Viable Count $\left(\mathbf{C F U} \mathbf{x 1 0}^{\mathbf{5}} \mathbf{g}^{\mathbf{- 1}}\right.$ ) } \\
\cline { 2 - 4 } & Winter & Summer & Rainy Season \\
\hline Heterotrophs & 4.0 & $8.4^{* *}$ & 3.5 \\
\hline Coliforms & $3.4^{*}$ & $6.0^{* *}$ & 1.7 \\
\hline Pseudomonas spp. & $3.6^{* *}$ & $8.2^{* * *}$ & 1.4 \\
\hline Azotobacter spp. & 3.3 & $7.2^{* *}$ & 2.5 \\
\hline Rhizobium spp. & 4.0 & $7.6^{*}$ & 2.8 \\
\hline
\end{tabular}

$\mathrm{CFU}=$ Colony forming unit, ${ }^{*} \mathrm{p}<0.05 ;{ }^{* *} \mathrm{P}<0.01 ; * * * \mathrm{p}<0.001$ 
Table.2 Plant growth promoting (PGP) traits in soil bacteria from SMOF

\begin{tabular}{|c|c|c|c|c|c|c|c|c|}
\hline \multirow[t]{2}{*}{ Organism } & \multirow[t]{2}{*}{ No. } & \multicolumn{7}{|c|}{ Incidence of PGP Traits (\%) } \\
\hline & & $\mathrm{NH}_{3}$ & $\mathrm{HCN}$ & SD & IAA & $\mathrm{ACCD}$ & PS & CT \\
\hline Heterotrophs & 149 & $145(97.3) * * *$ & $41(27.5)$ & $128(85.9) * * *$ & $135(90.6) * * *$ & $106(27.5)^{* *}$ & $29(19.4)$ & $113(75.8)^{* *}$ \\
\hline Coliforms & 107 & $86(80.3)^{* * *}$ & $3(2.8)$ & $35(32.7)^{* *}$ & $80(74.7)^{* * *}$ & $78(72.8) * * *$ & $43(40.1) * *$ & $86(80.3) * * *$ \\
\hline $\begin{array}{l}\text { Pseudomonas } \\
\text { spp. }\end{array}$ & 132 & $121(91.6) * * *$ & $81(61.3) * *$ & $111(84.0)^{* *}$ & $122(92.4) * * *$ & $118(89.3)^{* *}$ & $72(54.5) *$ & $123(93.1) * * *$ \\
\hline $\begin{array}{l}\text { Rhizobium } \\
\text { spp. }\end{array}$ & 132 & $129(97.7) * * *$ & $27(20.45)$ & $76(57.6) * *$ & $121(91.6)^{* * * *}$ & $112(84.8)^{* * *}$ & $65(49.2) * *$ & $117(88.6)^{* * *}$ \\
\hline $\begin{array}{l}\text { Azotobacter } \\
\text { spp. }\end{array}$ & 130 & $125(96.1) * * *$ & $28(21.5)$ & $99(76.1) * *$ & $125(96.1) * * *$ & $97(74.6) * *$ & $34(26.1)$ & $112(86.1) * * *$ \\
\hline Total $(\%)$ & 650 & $606(93.2) * * *$ & $180(27.6)$ & $449(69.0)^{* *}$ & $583(89.6) * * *$ & $511(78.6) * * *$ & $243(38.0) *$ & $551(85.0)^{* * *}$ \\
\hline
\end{tabular}

$* \mathrm{p}<0.05 ; * * \mathrm{P}<0.01 ; * * * \mathrm{p}<0.001$, Production of ammonia $\left(\mathrm{NH}_{3}\right)$, hydrogen cyanide (HCN), Siderophore (SD), indole acetic acid (IAA), 1-aminocyclopropane- 1-carboxylate deaminase (ACCD), phosphorus solubilization (PS) activity and Catalase (CT)

Table.3 Number of PGP Traits among bacterial isolates from SMOF

\begin{tabular}{|l|l|l|l|l|l|}
\hline Organisms & \multirow{2}{*}{$\begin{array}{l}\text { No. } \\
\text { isolates }\end{array}$} & of & \multicolumn{5}{|l|}{ No. of PGP traits (\%) } \\
\cline { 3 - 6 } & 149 & $\mathbf{0}$ & $\mathbf{1}$ & $\mathbf{2}$ & $\mathbf{2}$ \\
\hline Heterotrophs & & $16(10.7)$ & 00 & $01(0.6)$ & $\begin{array}{l}132 \\
(88.5)\end{array}$ \\
\hline Coliform & 107 & $02(1.8)$ & 00 & $02(1.8)$ & $\begin{array}{l}103 \\
(96.2)\end{array}$ \\
\hline Pseudomonas spp. & 132 & $10(9.3)$ & 00 & 00 & $\begin{array}{l}122 \\
(92.4)\end{array}$ \\
\hline Azotobacter spp. & 130 & $06(4.6)$ & 00 & 00 & $\begin{array}{l}124 \\
(95.3)\end{array}$ \\
\hline Rhizobium spp. & 132 & $06(4.5)$ & 00 & 00 & $\begin{array}{l}126 \\
(95.4)\end{array}$ \\
\hline Total & 650 & $40(6.1)$ & 00 & $03(0.4)$ & $607(93.3)$ \\
\hline
\end{tabular}

Table.4 Salt tolerance among bacterial isolates from SMOF

\begin{tabular}{|l|l|l|l|l|}
\hline Organisms & \multirow{2}{*}{$\begin{array}{l}\text { No. } \\
\text { isolates }\end{array}$} & \multicolumn{4}{|l|}{ No. of organisms tolerant to Salt $(\%)$} \\
\cline { 3 - 5 } & & $\mathbf{5}$ & $\mathbf{1 0}$ & $\mathbf{2 0}$ \\
\hline Heterotrophs & 149 & $125(83.8)$ & $24(16.1)$ & 0 \\
\hline Coliform & 107 & $84(78.5)$ & $23(21.4)$ & $2(1.8)$ \\
\hline Pseudomonas spp. & 132 & $105(79.5)$ & $26(19.6)$ & 0 \\
\hline Rhizobium spp. & 132 & $103(78.0)$ & $29(21.9)$ & 0 \\
\hline Azotobacter spp. & 130 & $66(50.7)$ & $63(48.4)$ & $1(0.7)$ \\
\hline Total & 650 & $483(74.3)$ & $165(25.3)$ & $3(0.4)$ \\
\hline
\end{tabular}


Table.5 Tolerance to $\mathrm{pH}$ among bacterial isolates from SMOF

\begin{tabular}{|l|l|l|l|l|l|l|l|l|}
\hline Organisms & \multirow{2}{*}{$\begin{array}{l}\text { No. of } \\
\text { isolates }\end{array}$} & \multicolumn{2}{|l|}{ No. of organisms tolerant to pH (\%) } \\
\cline { 3 - 9 } & 149 & $\mathbf{5 - 9}$ & $\mathbf{5 - 8}$ & $\mathbf{6 - 9}$ & $\mathbf{6 - 7}$ & $\mathbf{7}$ & $\mathbf{7 - 9}$ & $\mathbf{7 - 8}$ \\
\hline Heterotrophs & $143(82.0)$ & & $24(16.1)$ & 0 & 0 & 0 & $2(1.3)$ \\
\hline Coliform & 107 & $83(77.5)$ & $1(0.9)$ & $5(4.6)$ & $2(1.8)$ & $5(4.6)$ & $3(2.8)$ & $8(7.4)$ \\
\hline Pseudomonas spp. & 132 & $107(81.0)$ & 0 & $6(4.5)$ & 0 & $9(6.8)$ & $4(3.0)$ & $6(4.5)$ \\
\hline Rhizobium spp. & 132 & $88(66.6)$ & 0 & $1(0.7)$ & $3(2.2)$ & $33(25.0)$ & $5(3.7)$ & $2(1.5)$ \\
\hline Azotobacter spp. & 130 & $84(64.6)$ & 0 & $23(17.6)$ & 0 & $7(5.3)$ & $3(2.3)$ & $13(10.0)$ \\
\hline Total & 650 & $485(74.6)$ & $1(0.1)$ & $57(8.7)$ & $5(0.7)$ & $53(8.1)$ & $14(2.1)$ & $28(4.3)$ \\
\hline
\end{tabular}

Fig.1 PCA biplot of different groups of bacteria at three different seasons under organic farming

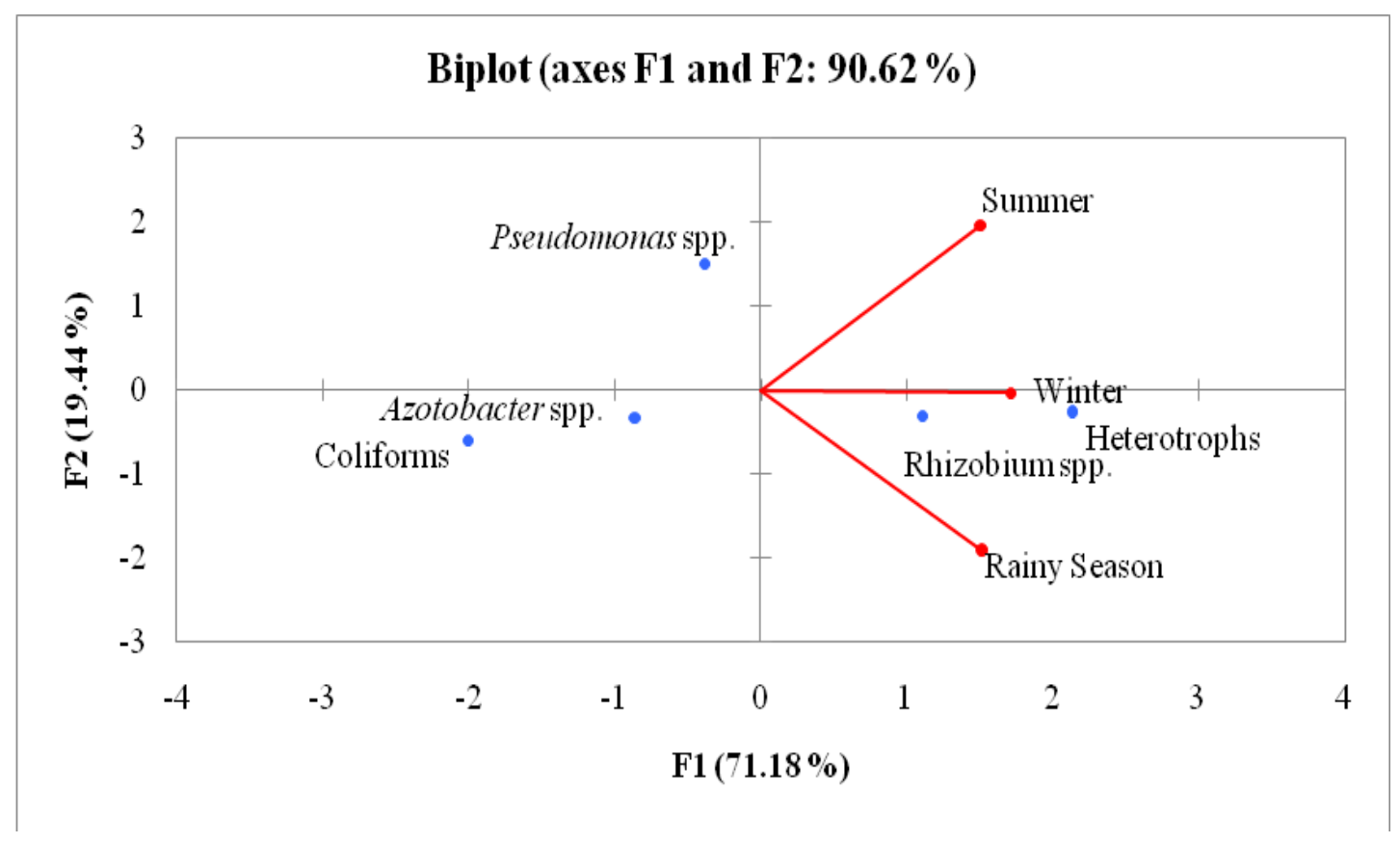

Fig.2 Distribution of MPGP traits among different bacterial groups

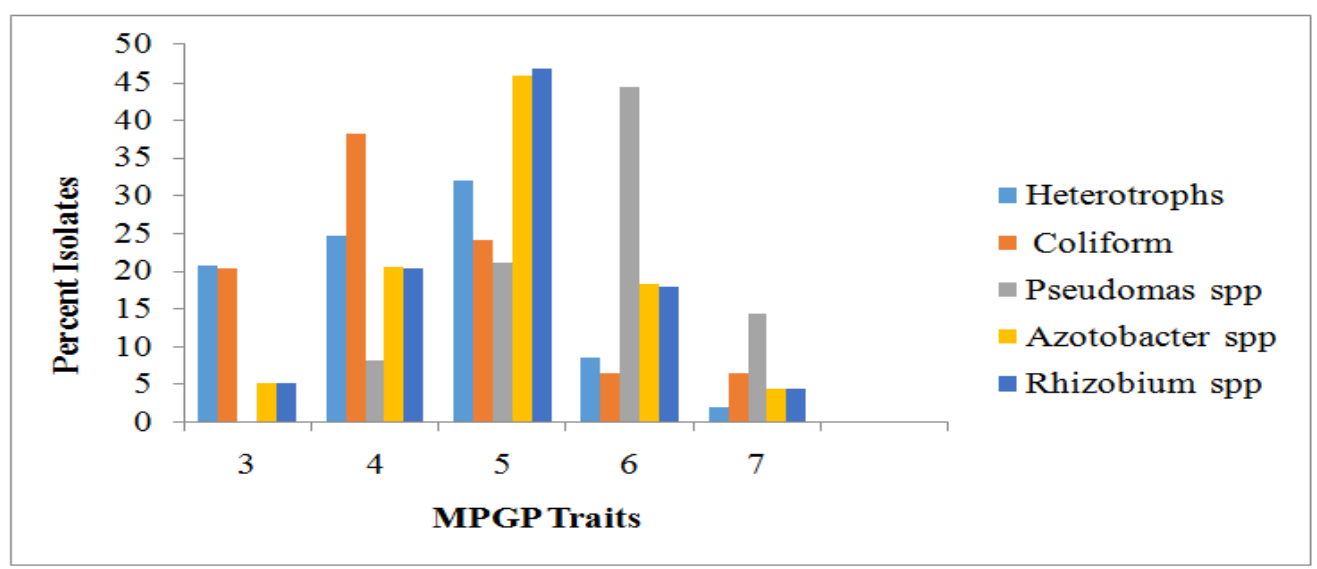


Fig.3 Seasonal variation of PGP traits in bacterial isolates from
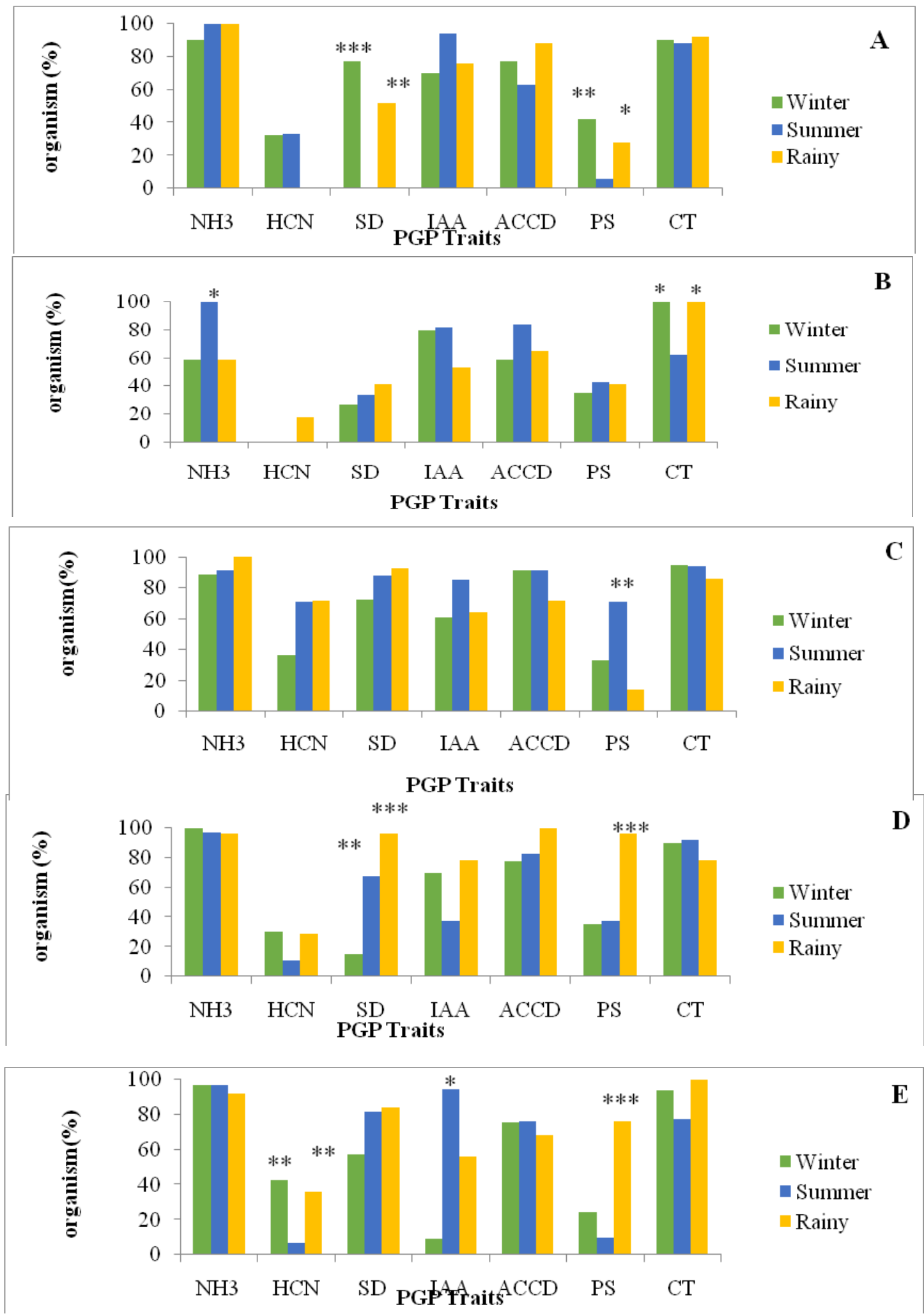

*p $<0.05 ; * * \mathrm{P}<0.01 ; * * * \mathrm{p}<0.0001$, A) Heterotrophs, B) Coliform, C) Pseudomonas spp., D) Rhizobium spp., E) Azotobacter spp. Production of ammonia (NH3), hydrogen cyanide (HCN), siderophore (SD), indole acetic acid (IAA), 1-aminocyclopropane- 1-carboxylate deaminase (ACCD) and phosphorus solubilization (PS) activity 
Production of IAA is widespread among rhizobacteria (Patten and Glick, 1996; Khalid et al., 2004; Spaepen et al., 2007) and is one of the most physiologically active auxin or phytohormones implicated in the regulation of plant growth and development. Researchers have observed an increase in root hairs and lateral roots thus increasing the total root surface leading to an enhanced mineral uptake from the soil by inoculation of plants with PGPR with ability to produce high levels of IAA (Patten and Glick, 2002; Aloni et al., 2006; Fukaki et al., 2007). PGPR mediated induction of seed germination and root and shoot length was demonstrated by several researchers (Anitha and Das, 2011; Ramteke et al., 2012).

In addition to its effect on plant growth, microbially produced IAA has been suggested to trigger an increased level of protection against external adverse conditions by coordinately enhancing different cellular defense systems. Because of this multiple effects on plants, many pathways such as tryptophol, tryptamine, indole-3-pyruvic acid and indole-3-acetamide pathways have been reported to be evolved in microorganism for IAA production (Gravel et al., 2007). Thus, IAA production-based screening can be considered as an effective tool for detecting beneficial microorganisms with regulatory effect on plant growth (Ali and Hasnain, 2007; Govindarajan et al., 2007). Microbes play an important role in the acquisition and transfer of nutrients in soil (Richardson, 2001). Therefore, the utilization of soil microbes to activate minerals and enhance nutrient uptake in plants has attracted increasing attention in sustainable agriculture (Fayez and Mahmoud, 2006).Phosphorus (P) is one of the major essential macronutrients for plants. In India, it is estimated that there are almost 260 million tons of phosphate rock deposits and this material should provide a cheap source of phosphate fertilizer for crop production (FAI 2002). Although in soil $\mathrm{P}$ is available abundantly, its bioavailability in soil remains low due to the chemical transformations of $\mathrm{P}$ into insoluble forms (Rodriguez and Fraga, 1999) and thus a major constraint to the plant growth and crop production (Chiquito-Contreras et al., 2012). Phosphate-solubilizing bacteria (PSB) have been considered as one of the possible alternatives for mediating inorganic phosphate solubilization and increasing its availability to the plants (Rodríguez et al., 2006).

In the present study, a significant number of organisms $(38 \%)$ displayed phosphate solubilizing activity. A study by Kaur and Reddy (2014) suggested that PSBs play an important role in improving crop productivity in organic farming. They noted significant increase in the biometric parameters (shoot height, shoot and root dry biomass) of maize and wheat plants after treatment with PSBs. Similar results were noted by other investigators (Dugar et al., 2013; Hassimi et al., 2013; Ranjan et al., 2013). In addition to PS activity, PSBs may also improve the plant productivity by producing other secondary metabolites. There are several evidences related to plant growth promotion by PSBs through the production of indole acetic acid (IAA) and siderophores (Hariprasad and Niranjana 2009). Few earlier studies established the relationship between $\mathrm{P}$ Solubilizing Index (PSI) and growth and physiological parameters of Phosphate solubilizing endophytes (Parihar et al., 2003; Parihar and Ramteke, 2003).

Iron $(\mathrm{Fe})$ is an essential plant micronutrient and microbial siderophores enhance Fe uptake by plants (Kloepper et al., 1980; Katiyar and Goel, 2004; Dimkpa et al., 2009) and thus plays an important role in plant growth promotion. Although large portion of $\mathrm{Fe}$ is present in soil, it acts as a limiting factor for 
plant growth because its existence in the form of highly insoluble ferric hydroxide. Bacteria secrete siderophores to solubilize $\mathrm{Fe}$ from their surrounding environments by forming a complex ferric-siderophore and provide it to the plants for growth promotion (Andrews et al., 2003). Siderophore mediated suppression of phytopathogens was reported by Jasim et al., (2015). Here, a physiological response is implied by the fact that HCN production is induced by iron (Bakker and Schippers, 1987; Keel et al., 1989; Voisard et al., 1989) and that it is under the strong influence of quorum sensing (Pessi and Haas, 2000). The latter is likely to happen particularly in the rhizosphere, where root exudation promotes high bacterial counts.

The enzyme 1-aminocyclopropane-1carboxylate deaminase (ACCD) is widely spread in bacteria (Belimov et al., 2001, Ghosh et al., 2003; Ma et al., 2003; Dey et al., 2004; Glick, 2005; Hontzeas et al., 2005; Blaha et al., 2006; Madhaiyan et al., 2006; Duan et al., 2009). It cleaves ACC, the immediate precursor of ethylene in plants and convert into ammonia and $\alpha$-ketobutyrate (Glick et al., 1998). These products of ACC cleavage are potential nitrogen and carbon sources (Glick et al., 1998) that can play a role in the microorganism's fitness under stressful situations. Under stress conditions plants produce higher levels of the phytohormones ethylene, which means that the plants also produce higher levels of ACC (Glick et al., 2007).

Under stress conditions, not only plant produce increased amount of ACC, the vast majority of rhizosphere microorganisms produce the phytohormone indole acetic acid (IAA) which acts to loosen plant cell walls thereby facilitating root exudation. In addition, bacterial IAA production has been shown to increase ACC synthase expression in plants (Kende, 1993). Thus, microorganisms that can produce IAA and utilize ACC may have a competitive advantage over other soil microorganisms (Glick et al., 1998, Stearns et al., 2012). It is know that ACCD modulates ACC metabolism and is related to plant growth promotion and microorganism's developmental processes (Nascimento et al., 2014) and thus protecting the plant from stress (Subramanian et al., 2015).

Studies reveal the role of ACCD in influencing the senescence of flowers and thereby increasing the shelf life (Ali et al., 2012; Jasim et al., 2015). Additionally, recent results suggest a considerable degree of horizontal ACCD gene transfer events (Nascimento et al., 2014). Hence, exploration of more ACCD gene from diverse bacterial sources and in depth understanding of the function of this enzyme especially in plant physiology signifies its importance. This may be the key molecule in a variety of important agricultural and biotechnological applications of ACCD genes and their expression (Nascimento et al., 2014).

Volatile compound HCN produced by rhizobacteria is mainly considered as a biocontrol agent against phytopathogenic fungi (Ramette et al., 2003; Ahmad et al., 2008; Rezzonico et al., 2007; Siddiqui et al., 2006).

It is proposed that $\mathrm{HCN}$ interrupts functioning of many enzymes (Cooper and Brown, 2008) or protein carriers and as a result inhibits the growth of certain organisms. Wei and coworkers (1991) opined the possibility of $\mathrm{HCN}$ inducing systemic resistance in some plants making them resistant to phytopathogen attack (Siegie'n and Bogatek, 2006).

Contrary to the role of $\mathrm{HCN}$ as abiocontrol agent, several researchers concluded that $\mathrm{HCN}$ is hardly a universal biocontrol agent 
and even caused phytotoxic effects in most in vitro experiments (Alström and Burns, 1989; Pal et al., 2000; Kremer and Souissi, 2001; Rudrappa et al., 2008; Blom et al., 2011). In a recent study by Rijavec and Lapanje (2016) have shown that there is no correlation between the amount of $\mathrm{HCN}$ produced by a particular strain and its ability to inhibit the growth of phytopathogenic bacteria or fungi. These workers proposed a new role for $\mathrm{HCN}$ production by rhizospheric bacteria. $\mathrm{HCN}$ seems to increases phosphate availability for rhizobacteria and plant hosts especially in oligotrophic alpine environments. Richness of their functional characteristics is further revealed by their tolerance salinity and wide range of $\mathrm{pH}$. Soil salinity and extreme $\mathrm{pH}$ are matter of serious concern for agricultural productivity. Use of salt tolerant PGPR is an effective approach to enhance growth and tolerance of various crops under salt stress conditions (Sharma et al., 2016). In the present study all isolates from organic farm were tolerant to $>5 \% \mathrm{NaCl}$ and wide range of $\mathrm{pH}$. Biologically nitrogen fixing organisms have a very important role in any agroecological system due to their ability to convert atmospheric nitrogen into fertilizer. In the present study we obtained major (96-97\%) constituent of bacterial population of nitrogen fixers Azotobacter spp. and Rhizobium spp with multiple PGP traits and tolerance to salinity and wide range of $\mathrm{pH}$.

Organic farming adopts a sustainable production practices in which low input system is aimed at mitigation of negative impact of conventional high input farming practices such as use of synthetic fertilizers, pesticides and other inputs (Gomiero et al., 2011).

It combines scientific knowledge of ecology and modern technology with traditional farming practices based on naturally occurring biological processes. Since organic farming avoids the inputs of synthetic chemicals, the build-up of a large and active soil microbial biomass is, therefore, critically important for sustaining the productivity of soils in organic farming systems (Tu et al., 2006).

Although crop productivity of organic farming is found reduced in the initial stages as compare to conventional farming practices that uses heavy chemical fertilizers and pesticides, in due course of time organic farming practices do give better results and helps positively in sustenance of soil health and microflora, which indirectly maintains the balance of nature. Organic farming system substantially reduces the use of synthetic fertilizers, pesticides, energy and mechanic stress and aims at mitigating negative impacts of high-input farming practices in order to improve sustainable production (Gomiero et al., 2011). Over the years, organic systems revealed an increase in microbial biomass and activity, largely driven by quantity and quality of farmyard manure (Fliessbach et al., 2007; Birkhofer et al., 2008).

The studies demonstrated the clear difference between soil microbiom associated with organic amendments and chemical fertilizers (Ling et al., 2016). Organic fertilizer applications interact with soil chemical properties and boost soil fertility thereby significantly impacting the associated soil biodiversity making ecosystem more resilient to stress (Liu et al., 2016; Ling et al., 2017). Most functional groups involving nutrient related metabolism and recycling at significantly high abundance in organic amended soil. Changes in soil environmental conditions exert strong effects on microbial diversity, phylotype composition and ecosystem function (Xun et al., 2016).

Long term organic amendments support stronger functional potentials of organic farm 
system. Other organic amendment benefits are soil stability and buffering capacity (Ling et al., 2016), increase in soil carbon stocks (Xie et al., 2014) and improvement in soil structure and water retention ( $\mathrm{Yu}$ et al., 2012), soil enzyme activities (Bowles et al., 2014; Kotroczo et al., 2014), and that they simultaneously provides maintenance of soil health (Chaparro et al., 2012) and suppression of soil-borne diseases (Qiu et al., 2012) Diverse types of long-term fertilization management at the study site exert significantly different effects on soil physical and chemical properties (Xun et al., 2016). In the long run organic farming system emerges as a sustainable adaptive agricultural practice that is less dependent on external high inputs and maintains the productive agro ecosystem that will meet our food and nutritional requirements.

The present study demonstrated that organic farming system enriches soil bacterial diversity and soil fertility and rendering the agro ecosystem less dependent on external high inputs. We observe rich bacterial diversity in MOF soil both in terms of their types and functional (PGP) traits. Bacterial isolates were predominantly positive to production of ammonia, IAA, catalase, ACCD and siderophore. Richness of their functional characteristics further revealed by their tolerance to salinity and wide range of $\mathrm{pH}$. Organic farming system offers huge promise of achieving ecological, economic and social stability in food production system. However, organic farming is faced with a need to expand and develop in line with increasing demands for food and growing environmental concerns.

\section{Acknowledgements}

The authors wish to thank the Vice Chancellor, SHUATS for providing the necessary facilities for this study. AS acknowledges the financial support of Rajiv Gandhi National Fellowship (RGNF) by University Grants Commission, India. Authors are grateful to Dr. B. N. Paul for critical review of the manuscript.

\section{References}

Abraham, T., 2009. Organic farming: the ultimate strategy to combat antimicrobial resistance, (In) Proceedings of National Conference on Antimicrobial Resistance: From Emerging Threat to Reality; Rubina Lawrence (Ed.). Narosa Publishing House Pvt. Ltd., New Delhi, 1st ed. 174-181.

Abraham, T., 2011. Final Report of National Project on Organic Farming (NPOF), sponsored by National Centre of Organic Farming, Ghaziabad and Ministry of Agriculture, Government of India. $451+\mathrm{ii}$.

Abraham, T., 2013. Eco Organic Agriculture and SRI, LEISA India, 15:37.

Abraham, T., Miura, T., Kumar, S., 2013. Potential for Small Holders Entrepreneurship for Sustainability through Organic Farming in the Indo-Gangetic Plains of Asia-Pacific - Models Worth Emulation, In: Proceedings of AsiaPacific Regional Symposium on 'Entrepreneurship and Innovation in Organic Farming'. December, Bangkok, Thailand.

Abraham, T., Sagar, A., Ramteke, P. W., Singh, S., 2016. Potentials for Scaling-up efforts through Farmers' Adaptation of System of Rice Intensification (SRI) - approach to tackle unsustainable RWCS of NEPZ. System of Rice intensification, Studium Press (India) Pvt. Ltd. Section -III Chapter -12.

Ahmad, F., Ahmad, I., Khan, M.S., 2008. Screening of free-living rhizospheric bacteria for their multiple plant growth promoting activities. Microbiol. Res. 163:173-181.

Ali, B., Hasnain, S., 2007. Potential of bacterial indoleacetic acid to induce adventitious shoots in plant tissue culture. Lett. Appl. Microbiol. 45: 128-133.

Ali, S., Charles, T. C., Glick, B. R., 2012. Delay of carnation flower senescence by bacterial endophytes expressing ACC deaminase. $J$. Appl. Micro. 113:1139-1144.

Aloni, R., Aloni, E., Langhans, M., Ullrich, C. I., 2006. Role of cytokinin and auxin in shaping root architecture: regulating vascular 
differentiation, lateral root initiation, root apical dominance and root gravitropism. Ann. Bot. 97:883-893.

Alström, S., Burns, R. G., 1989. Cyanide production by rhizobacteria as a possible mechanism of plant growth inhibition. Biol. Fertil. Soils. 7:232-238.

Andrews, S. C., Robinson, A. K., Rodríguez, Q. F., 2003. Bacterial iron homeostasis. FEMS Micro. Reviews. 27: 215-237.

Anitha, A., Das, M. A., 2011. Activation of rice plant growth against Rhizoctoniasolani using Pseudomonas fluorescens, Trichoderma. Res. Biotech. 2:07-12.

Bakker, A. W., Schippers, B., 1987. Microbial cyanide production in the rhizosphere in relation to potato yield reduction and Pseudomonas spp. mediated plant growth stimulation. Soil Biol. Biochem. 19: 451-457.

Belimov, A. A., Safronova, V. I., Sergeyeva, T. A., Egorova, T.N., Matveyeva, V.A., Tsyganov, V.E., Borisov, A.Y., Tikhonovich, I.A., Kluge, C., Preisfeld, A., Dietz, K., Stepanok, V. V., 2001. Characterization of plant growth promoting rhizobacteria isolated from polluted soils and containing 1-aminocyclopropane-1carboxylate deaminase. Can. J. Microbiol. 47: 642-652.

Berger, L.R., Stamford, N.P., Santos, C.E.R.S., Freitas, A.D.S., Franco, L.O., Stamford, T.C.M., 2013. Plant and soil characteristics affected by biofertilizers from rocks and organic matter inoculated with diazotrophic bacteria and fungi that produce chitosan. J. Soil Sci. Plant Nutr. 13: 592-603.

Bhardwaj, D., Ansari, M.W., Sahoo, R.K., Tuteja, N., 2014. Biofertilizers function as key player in sustainable agriculture by improving soil fertility, plant tolerance and crop productivity. Microb. Cell Fact. 13, 66.

Birkhofer, K., Bezemer, T.M., Bloem, J., Bonkowski, M., Christensen, S., Dubois, D., Ekelund, F., Fließbach, A., Gunst, L., Hedlund, K., Mikola, J., Robin, C., Seta, H., Ma, P., Putten, W.H. Van Der, Scheu, S., 2008. Longterm organic farming fosters below and aboveground biota: Implications for soil quality, biological control and productivity. Soil Bio. Biochem. 40: 2297-2308.

Blaha, D., Prigent-Combaret, C., Mirza, M.S., Moenne-Loccoz, Y., 2006. Phylogeny of the 1aminocyclopropane-1-carboxylic acid deaminase-encoding gene acdS in phytobeneficial and pathogenic proteobacteria and relation with strain biogeography. FEMS Microbiol. Ecol. 56: 455-470.

Blom, D., Fabbri, C., Eberl, L., Weisskopf, L., 2011. Volatile-mediated killing of Arabidopsisthaliana by bacteria is mainly due to hydrogen cyanide. Appl. Environ. Microbiol. 77: 1000-1008.

Bohme, L., Langer, U., Bohme, F., 2005. Microbial biomass, enzyme activities and microbial community tructure in two European long-term field experiments. Agric. Ecosyst. Environ. 109: 141-152.

Bowles, T. M., Acosta-Martínez, V., Calderón, F., Jackson, L.E., 2014. Soil enzyme activities, microbial communities, and carbon and nitrogen availability in organicagroecosystems across an intensively-managed agricultural landscape. Soil Biol.Biochem. 68: 252-262.

Brick, J. M., Bostock, R. M., Silverstone, S. E., 1991. Rapid in situ assay for indole acetic acid production by bacteria immobilized on nitrocellulose membrane. Appl. Enviro. Micro. 57: 535-538.

Brussaard, L., De Ruiter, P.C., Brown, G.G., 2007. Soil biodiversity for agricultural sustainability. Agr. Ecosyst. Environ. 121: 233-244.

Cappuccino, J.C., Sherman, N., 1992. In: microbiology; A laboratory manual $3^{\text {rd }}$ ed. Benjamin/cummings pub. Co., New York, 125 179.

Chaparro, J., Sheflin, A., Manter, D., Vivanco, J. 2012. Manipulating the soil micro-biome to increase soil health and plant fertility. Biol. Fertil. Soils, 48: 489-499.

Chiquito Contreras, R.G., Osorio-Acosta, F., GarciaPerez, E., Villanueva-Jimenez, J.A., Zulueta Rodriguez, R., Castillo Rocha, D.G. 2012. Biofertilization with rhizobacteria and a consortium of arbuscular mycorrhizal fungi in citrus root stocks. Trop. Subtrop. Agroecosyst. 15, S72-S81.

Chu, H., Lin, X., Fujii, T., Morimoto, S., Yagi, K., Hu, J., Zhang, J., 2007. Soil microbial biomass, dehydrogenase activity, bacterial community structure in response to long-term fertilizer management. Soil Biol. Biochem. 39: 29712976.

Cooper, C.E., Brown, G.C. 2008. The inhibition of mitochondrial cytochrome oxidase by the gases carbon monoxide, nitric oxide, hydrogen cyanide and hydrogen sulfide: chemical mechanism and physiological significance. $J$. 
Bioenerg. Biomembr. 40: 533-539.

Damodaran, T., Sah, V., Rai, R.B., Sharma, D.K., Mishra, V.K., Jha, S.K., Kannan, R. 2013. Isolation of salt tolerant endophytic and rhizospheric bacteria by natural selection and screening for promising plant growth-promoting rhizobacteria (PGPR) and growth vigour in tomato under sodic environment. Afri. $J$. Microbiol. Res. 7: 5082-5089.

Das, B.B., Dkhar, M.S. 2011. Rhizosphere Microbial Populations and Physico Chemical Properties as Affected by Organic and Inorganic Farming Practices. Environ. Sci. 10: 140-150.

Debbarma, V., Abraham, T. 2015. Quality of organic rice [Oryza sativa (L.) sub sp. japonica] as influenced by planting methods and nutrient management. New Agricult. 26: 341-346.

Dey, R., Pal, K.K., Bhatt, D.M., Chauhan, S.M. 2004. Growth promotion and yield enhancement of peanut (Arachis hypogaea L.) by application of plant growth-promoting rhizobacteria. Microbiol. Res. 159: 371-394.

Dimkpa, C.O., Merten, D., Svatos, A., Büchel, G., Kothe, E. 2009. Siderophores mediate reduced and increased uptake of cadmium by Streptomyces tendae F4 and sunflower (Helianthus annuus), respectively. J. Appl. Microbiol. 107: 1687-1696.

Duan, J., Müller, K.M., Charles, T.C., Vesely, S., Glick, B.R. 2009. 1-Aminocyclopropane-1carboxylate (ACC) deaminase genes in rhizobia from southern saskatchewan. Microb. Ecol. 57: 423-436.

Dugar, G., Herbig, A., Förstner, K.U., Heidrich, N., Reinhardt, R., Nieselt, K., Sharma, C.M. 2013. High-Resolution Transcriptome Maps Reveal Strain-Specific Regulatory Features of Multiple Campylobacter jejuni Isolates. PLoS Genet. 9.

Esperschütz, J., Gattinger, A., Mäder, P., Schloter, M., Fließbach, A. 2007. Response of soil microbial biomass and community structures to conventional and organic farming systems under identical crop rotations. FEMS Microbiol. Ecol. 61: 26-37.

Fayez, R., Mahmoud, G. 2006. Interactions between phosphorus availability and an AM fungus (Glomus intraradices) and their effects on soil microbial respiration, biomass and enzyme activities in a calcareous soil.Pedobiol. 50, 413425.

Fertilizer Association of India (FAI). 2002. Fertilizer statistics. New Delhi, India. I: 39-47.

Fliessbach, A., Oberholzer, H.-R., Gunst, L., Mader,
P. 2007. Soil organic matter and biological soil quality indicators after 21 years of organic and conventional farming. Agric. Ecosyst. Environ. 118: 273-284.

Fukaki, H., Okushima, Y., Tasaka, M., 2007. Auxin - Mediated Lateral Root Formation in Higher Plants.Interna. Rev. Cytol. 256: 111-137.

Gardner, T., Acosta-Martinez, V., Senwo, Z., Dowd, S.E. 2011. Soil rhizosphere microbial communities and enzyme activities under organic farming in Alabama. Diversit. 3: 308328.

Ghosh, S., Penterman, J.N., Little, R.D., Chavez, R., Glick, B.R. 2003. Three newly isolated plant growth-promoting bacilli facilitate the seedling growth of canola, Brassica campestris. Plant Physo. Biochem. 4: 277-281.

Girvan, M.S., Campbell, C.D., Killham, K., Prosser, J.I., Glover, L.A. 2005. Bacterial diversity promotes community stability and functional resilience after perturbation. Environ. Microbiol. 7: 301-313.

Glick, B.R. 2005. Modulation of plant ethylene levels by the bacterial enzyme ACC deaminase. FEMS Microbiol. Lett. 251: 1-7.

Glick, B.R., Cheng, Z., Czarny, J., Duan, J. 2007. Promotion of plant growth by ACC deaminaseproducing soil bacteria. Eur. J. Plant. Pathol. 119: 329-339.

Glick,B.R., Penrose, D. M., Li, J. 1998. A model for the lowering of plant ethylene concentrations by plant growth-promoting bacteria. J. Theor. Biol. 190: 63-68.

Gomiero, T., Pimentel, D., Paoletti, M.G. 2011. Environmental Impact of Different Agricultural Management Practices: Conventional vs. Organic Agriculture. CRC. Crit. Rev. Plant Sci. 30: 95-124.

Govindarajan, M., Kwon, S., Weon, H. 2007. Isolation, molecular characterization and growth-promoting activities of endophytic sugarcane diazotroph Klebsiella sp. GR9.World J. Microbiol. Biotechnol. 23: 997-1006.

Grantina, L., Kenigsvald, K., Eze, D., Petrina, Z., Skrabule, I., Rostoks, N., Nikolajeva, V. 2011. Impact of six-year-long organic cropping on soil microorganisms and crop disease suppressiveness. Zemdir. Agricult. 98: 399-408.

Gravel, V., Antoun, H., Tweddell, R. J. 2007. Growth stimulation and fruit yield improvement of greenhouse tomato plants by inoculation with Pseudomonas putida or Trichoderma atroviride: possible role of indole acetic acid 
(IAA). Soil Biolo. Biochem. 39: 1968-1977.

Gu, Y., Zhang, X., Tu, S., Lindstro, K. 2009. Soil microbial biomass, crop yields, and bacterial community structure as affected by long-term fertilizer treatments under wheat-rice cropping. E. J. Soil Biol. 45: 239-246.

Hariprasad, P., Niranjana, S. R., 2009. Isolation and characterization of phosphate solubilizing rhizobacteria to improve plant health of tomato. Plant Soil. 316: 13-24.

Hartmann, M., Frey, B., Mayer, J., Mäder, P., Widmer, F. 2014. Distinct soil bacterial diversity under long-term organic and conventional farming. ISME J. 9: 1177-1194.

Hassimi, M. S., Hamdali, H., Ouhdouch, Y., Pinelli, E., Merlina, G., Claude, R. J., Hafidi, M. 2013. Moroccan rock phosphate solubilization during a thermo-anaerobic grassland waste biodegradable process. Afri. J. Biotech.12: 6859-6865.

Hontzeas, N., Richardson, A.O., Belimov, A., Safronova, V., Abu- Omar, M.M., Glick, B.R. 2005. Evidence for horizontal transfer of 1aminocyclopropane-1-carboxylate deaminase genes. Appl. Environ. Microbiol. 11: 75567558.

Jasim, B., Anish, M.C., Shimil, V., Jyothis, M., Radhakrishnan, E.K. 2015. Studies on plant growth promoting properties of fruit-associated bacteria from Elettaria cardamomum and molecular analysis of ACC Deaminase Gene. Appl. Biochem. Biotechnol. 177: 175-189.

Joseph, B., Patra, R.R., Lawrence, R., 2007. Characterization of plant growth promoting rhizobacteria associated with chickpea (Cicer arietinum L.). Int. J. Plant Prod. 1: 141-151.

Katiyar, V., Goel, R. 2004. Siderophore mediated plant growth promotion at low temperature by mutant of fluorescent pseudomonad. Plant Growth Regul. 42: 239-244.

Kaur, G., Reddy, M.S. 2014. Role of phosphatesolubilizing bacteria in improving the soil fertility and crop productivity in organic farming. Arch. Agron. Soil Sci. 60: 549-564.

Keel, C., Voisard, C., Berling, C., Kahr, G., Défago, G. 1989. Iron sufficiency, a prerequisite for the suppression of tobacco black root rot by Pseudomonas fluorescens strain CHA 0 under gnotobiotic conditions. Phytopathol. 79: 584589.

Kende, H., 1993. Ethylene biosynthesis.Annu. Rev. Plant Physiol. Plant Mol. Biol. 44: 283-307.

Khalid, A., Arshad, M., Zahir, Z.A. 2004. Screening plant growth-promoting rhizobacteria for improving growth and yield of wheat. J. Appl. Microbiol. 96: 473-480.

Kloepper, J.W., Leong, J., Teintze, M., Schroth, M.N. 1980. Enhanced plant growth by siderophores produced by plant growthpromoting rhizobacteria. Nature. 286: 885-886.

Kotroczo', Z., Veres, Z., Fekete, I., Krakomperger, Z., To'th, J.A., Lajtha, K., To'thme're'sz, B. 2014. Soil enzyme activity in response to longterm organic matter manipulation. Soil Biol. Biochem. 70: 237-243.

Kremer, R.J., Souissi, T. 2001. Cyanide production by rhizobacteria and potential for suppression of weed seedling growth, C. Microbiol. 43: 182186.

Ling, N., Chen, D., Guo, H., Wei, J., Bai, Y., Shen, Q., Hu, S., 2017. Differential responses of soil bacterial communities to long-term $\mathrm{N}$ and Pinputs in a semi-arid steppe. Geoderma. 292, 25-33.

Ling, N., Zhu, C., Xue, C., Chen, H., Duan, Y., Peng, C., Guo, S. and Shen, Q., Hu, S., 2016. Insight into how organic amendments can shape the soil microbiome in long-term field experiments as revealed by network analysis. Soil Biol. Biochem. 99, 137-149.

Liu, T., Whalen, J.K., Shen, Q., Li, H., 2016. Increase in soil nematode abundance due to fertilization was consistent across moisture regimes in a paddy rice-upland wheat system. Eur. J. Soil Biol. 72, 21-26.

Lopes, A.R., Faria, C., Prieto-Fernández, Á., TrasarCepeda, C., Manaia, C.M., Nunes, O.C., 2011. Comparative study of the bacterial diversity of bulk paddy soil of two rice fields subjected to organic and conventional farming. Soil Biol. Biochem. 43, 115-125.

Lorck, H. 1948. Production of hydrocyanic acid by bacteria. Plant Physiol. 142 -146.

Lupatini, M., Korthals, G.W., Hollander, M.,D., Janssens, T.K., Kuramae, E. E., 2017. Soil Microbiome Is More Heterogeneous in Organic Than in Conventional Farming System. Front. Microbiol. 7.2064.

Ma, W., Guinel, F.C., Glick, B.R., 2003. Rhizobium leguminosarum biovar viciae 1aminocyclopropane-1-carboxylate deaminase promotes nodulation of pea plants. Appl. Environ. Microbiol. 69, 4396-4402.

Mader, P., Fliefback, A., Dubois, D. Gunst, L., Fried, P., Niggili, U. 2002. Soil fertility and biodiversity in organic farming. Sci. 296: 1694- 
1697.

Madhaiyan, M., Poonguzhali, S., Ryu, J., Sa, T., 2006. Regulation of ethylene levels in canola (Brassica campestris) by 1-aminocyclopropane1-carboxylate deaminase-containing Methylobacterium fujisawaense. Planta. 224, 268-278.

Marschner, P., Kandeler, E., Marschner, B., 2003. Structure and function of the soil microbial community in a long-term fertilizer experiment. Soil Biol. Biochem. 35, 453-461.

Narula, N., Gupta, K.G., 1986. Ammonia excretion by Azotobacter chroococcum in liquid culture and soil in the presence of manganese and clay minerals. Plant Soil. 93, 205- 209.

Nascimento, F.X., Rossi, M.J., Soares, C., R., F., S., McConkey, B.J., Glick, B.R., 2014. New insights into 1-aminocyclopropane-1carboxylate (ACC) deaminase phylogeny, evolution and ecological significance. PLoS One 9, e99168.

Nautiyal, C.S., 1999. An efficient microbiological growth medium for screening phosphate solubilizing microorganisms. FEMS Microbiol. L. 170: 265- 270

Norris, J.R., Chapman, H.M., 1968. Classification of Azotobacter. In: Identification methods for microbiologists Gibbs B.M. and Shapton D.A. (Eds.) Academic press London and New York. 19-27.

Pal, K.K., Tilak, K.V., Saxena, A.K., Dey, R., Singh, C.S., 2000. Antifungal characteristics of a fluorescent Pseudomonas strain involved in the biological control of Rhizoctonia solani. Microbiol. Res. 155, 233-242. doi:10.1016/S0944- 5013(00)80038-5.

Parihar, D.K., Ramteke, P.W., 2003. Characterization of phosphate solubilizing sugarcane endophytes. Allah. Far. 2: 93-96.

Parihar, D.K., Ramteke, P.W., Suman, A. 2003. Phosphate solubilizing activity of endophytic bacteria isolated from sugarcane plant. Proceed. Nation. Acad. Sci. 73, 247-254.

Patten, C.L., Glick, B.R. 1996. Bacterial biosynthesis of indole-3-acetic acid. Can. J. Microbiol. 42: 207-220.

Patten, C.L., Glick, B.R. 2002. Role of Pseudomonas putida indoleacetic acid in development of the host plant root system. Appl. Environ. Microbiol. 68: 3795-801. doi:10.1128/AEM.68.8.3795.

Pessi, G., Haas, D. 2000. Transcriptional control of the hydrogen cyanide biosynthetic genes hon
$\mathrm{ABC}$ by the anaerobic regulator anr and the quorum-sensing quorum-sensing regulators Las $\mathrm{R}$ and RhlR in Pseudomonas aeruginosa. J. Bacteriol. 182: 6940-6949.

Qiu, M., Zhang, R., Xue, C., Zhang, S., Li, S., Zhang, N., Shen, Q. 2012. Application of bioorganic fertilizer can control Fusarium wilt of cucumber plants by regulating lating microbial community of rhizosphere soil. Biol. Fertil. Soils. 48: 807-816.

Rahmann, G., 2011. Biodiversity and Organic farming: What do we know? VTI Agric. For. Res. 3: 189-208.

Ram, B. 2003. Impact of Human Activities on Land Use Changes in Arid Rajasthan: Retrospect and Prospects. In: Narain, P., Kathju, S., Kar, A., Singh, M.P. and Praveen-Kumar, Eds., Human Impact on Desert Environment, Scientific Publishers, Jodhpur, 44-59.

Ramette, A., Frapolli, M., De'fago, G., Moe"nneLoccoz, Y. 2003. Phylogeny of HCN synthaseencoding honBC genes in biocontrol fluorescent pseudomonads and its relationship with host plant species and $\mathrm{HCN}$ synthesis ability. Mol Plant Microbe. Int. 16: 525-535.

Ramteke, P.W., Joseph, B., Mani, A, Chacko, S. 2012. Pisum sativum and associated Plant Growth Promoting Rhizobacteria: Effect of normal and sewage irrigation. Internatio. J. Soil Sci. 7: 15-27.

Ranjan, J., K., Ahmed, N., Das, B., Ranjan, P., Mishra, B., K. 2013. Green Technology for Production of Baby Corn (Zea mays L.) Under North-West Himalayan Conditions. Int. J. Chem. Tech. Res. 5: 880-885.

Rezzonico, F., Zala, M., Keel, C., Duffy, B., Moënne-Loccoz, Y., Défago, G. 2007. Is the ability of biocontrol fluorescent pseudomonads to produce the antifungal metabolite 2,4diacetylphloroglucinol really synonymous with higher plant protection. New Phytol. 173: 861872.

Richardson, A. E. 2001. Prospects for using soil microorganism to improve the acquisition of phosphorus by plants. Aust. J. Plant Physio. 28: 897-906.

Rijavec, T., Lapanje, A., 2016. Hydrogen Cyanide in the Rhizosphere: Not Suppressing Plant Pathogens, but Rather Regulating Availability of Phosphate. Front. Microbiol. 7: 1785.

Rodriguez, H., Frago R. 1999. Phosphate solubilising bacteria and their role in plant growth promotion. Biotechnol. Adv. 17: 319- 
339.

Rodríguez, J.P., Beard, T. D., Jr.2, Bennett, E. M., Cumming, G.S., Cork, S.J., Agard, J., Dobson, A. P., Peterson, G.D.2006. Trade-offs across space, time, and ecosystem services. Eco. Soc. 11: 28 .

Rudrappa, T., Splaine, R.E., Biedrzycki, M.L., Bais, H.P. 2008. Cyanogenic pseudomonads influence multi trophic interactions in the rhizosphere. PLoS ONE3, e2073.

Safronova, V.I., Stepanok, V. V., Engqvist, G.L., Alekseyev, Y. V., Belimov, A.A. 2006. Rootassociated bacteria containing 1aminocyclopropane-1-carboxylate deaminase improve growth and nutrient uptake by pea genotypes cultivated in cadmium supplemented soil. Biol. Fertil. Soils. 42: 267-272.

Saraf, M., Thakker, A., Patel, B.V., 2008. Biocontrol activity of different species of Pseudomonas against phytopathogenic Fungi In vivo and In vitro conditions.Int. J. Biotechnol. Biochem. 4: 11-18.

Schaad, N., W. 1992. Laboratory Guide for Identification of Plant Pathogenic Bacteria, $2^{\text {nd }}$ Edition, International Book Distributing Co., Lucknow, 44-58.

Schmid, F., Moser, G., Muller, H., Berg, G. 2011. Functional and Structural Bacterial diversityin Organic and Conventional Viticulture: Organic Farming Benefits Natural Biocontrol Agents. Appl. Environ. Microbio. 77: 2188-2191.

Sharma, S., Kulkarni, j., Jha, B., 2016. Halotolerant Rhizobacteria Promote Growth and Enhance Salinity Tolerance in Peanut. Front. Microbiol. 7: 1600 .

Siddiqui, I.A., Shaukat, S.S., Sheikh, I.H., Khan, A., 2006. Role of cyanide production by Pseudomonas fluorescens CHA0 in the suppression of root-knot nematode, Meloidogyne javanica in tomato. World $J$. Microbiol. Biotechnol. 22: 641-650.

Siegie'n, I., Bogatek, R.2006. Cyanideaction in plants fromtoxic to regulatory. Acta. Physiol. Plant. 28: 483-497.

Singh, G., Kumar, D., Sharma, P., Krakauer, N. 2015. Effect of organics, biofertilizers and crop residue application on soil microbial activity in rice - wheat and rice-wheat mungbean cropping systems in the Indo-Gangetic plains. Cogent Geosci. 1, 1085296.

Spaepen, S., Vanderleyden, J., Remans, R. 2007. Indole-3-aceticacid in microbial and microorganism-plant signaling. FEMS
Microbiol. Rev. 31: 425-448.

Stearns, J., C., Woody, O., Z., McConkey, B., J., Glick, B.,R. 2012. Effects of bacterial ACC deaminase on Brassica napus gene expression. Mol. Plant. Microbe. Interact. 25: 668-676.

Stockdale, E.A., Banning, N.C., Murphy, D. V. 2013. Rhizosphere effects on functional stability of microbial communities in conventional and organic soils following elevated temperature treatment. Soil Biol. Biochem. 57, 56-59.

Subramaniam, G. k., Sathya, A., Vijayabharathi, R., Varshney, R. K., Gowda, C.L.L., Krishnamurthy, L. 2014. Plant growth promoting rhizobia: challenges and opportunities. Biotech 5, 355-377.

Subramanian, P., Krishnamoorthy, R., Chanratana, M., Kim, K., Sa, T.2015. Expression of an exogenous 1- aminocyclopropane-1-carboxylate deaminase gene in psychrotolerant bacteria modulates ethylene metabolism and cold induced genes in tomato under chilling stress. Plant Physiol. Biochem., 89: 18-23.

Tu, C., Ristaino, J. B., Hu, S. 2006. Soil microbial biomass and activity in organic tomato farming systems: effects of organic inputs and straw mulching. Soil Biol. Biochem. 38: 247-255.

Tuck, S.L., Winqvist, C., Mota, F., Ahnström, J., Turnbull, L., A., Bengtsson, J., 2014. Land-use intensity and the effects of organic farming on biodiversity: a hierarchical meta-analysis. $J$. Appl. Ecol. 51: 746-755.

Vincent, J. M., 1970. A Manual for the practical study of the root nodule bacteria. Blackwall scientific publication, Oxford and Edinburgh. Pp. 1-3.

Voisard, C., Keel, C., Haas, D., and Dèfago, G. 1989. Cyanide production by Pseudomonas fluorescens helps suppress black root rot of tobacco under gnotobiotic conditions. EMBO J. 8,351 .

Wang, S., Li, Z., Fan, G. 2012. Soil quality and microbes in organic and conventional farming systems. Afr. J. Microbiol. Res. 6: 5077-5085.

Wei, G., Kloepper, J.W., TuZun, S., 1991. Induction of systemic resistance of cucumber to Colletotrichum orbiculare by select strains of plant growth- promoting rhizobacteria. Phytopathol. 81, 1508-1512. doi: 10.1094/Phyto- 81-1508

Xie, H., Li, J., Zhu, P., Peng, C., Wang, J., He, H., Zhang, X., 2014. Long-term manure amendments enhance neutral sugar 
accumulation in bulk soil and particulate organic matter in a Mollisol. Soil Biol. Biochem. 78, 45e53.

Xun, W., Zhao, J., Xue, C., Zhang, G., Ran, W., Wang, B., Shen, Q., Zhang, R., 2016. Significant alteration of soil bacterial com munities and organic carbon decomposition by different long term fertilization management conditions of extremely low-productivity arable soil in South China. Environ. Microbiol.18: 1907-1917.

Yao, X. H., Min, H., Lu, Z. H., Yuan, H.2006. Influence of acetamprid on soil enzymatic activities and respiration. Eur. J. Soil Biol. 42:
120-126.

Yu, H.Y., Ding, W.X., Luo, J.F., Donnison, A., Zhang, J.B., 2012. Long-term effect of compost and inorganic fertilizer on activities of carboncycle enzymes in aggregates of an intensively cultivated sandy loam. Soil use manag. 28: 347360 .

Zhen, Z., Liu, H., Wang, N., Guo, L., Meng, J., Ding, N., Wu, G., Jiang, G., 2014. Effects of manure compost application on soil microbial community diversity and soil microenvironments in a temperate cropland in China. PLoS One 9.

\section{How to cite this article:}

Alka Sagar, Victor Debbarma, Thomas Abraham, Pradeep K. Shukla and Pramod W. Ramteke. 2017. Functional Diversity of Soil Bacteria from Organic Agro Ecosystem. Int.J.Curr.Microbiol.App.Sci. 6(12): 3500-3518. doi: https://doi.org/10.20546/ijcmas.2017.612.408 